\title{
The dynamics of public support for the king in Yogyakarta
}

\section{Dinamika dukungan masyarakat terhadap raja di Yogyakarta}

\author{
Pajar Hatma Indra Jaya \\ Department of Islamic Community Development, Universitas Islam Negeri Sunan Kalijaga \\ Jalan Marsda Adisucipto, Yogyakarta 55281 \\ E-mail: pajar.jaya@uin-suka.ac.id
}

\begin{abstract}
The background of this research is the support of the people of Yogyakarta to the sultan to lead Daerah Istimewa Yogyakarta. This paper is aimed at examining the relationship between a king and the community in the democracy era. The cases examined specifically in this study were the case of the proposed law of Yogyakarta in the Sutet region, and the ore mining case in Kulonprogo. Research was conducted qualitatively by collecting data through documentation, observation and interview. Informant retrieval technique is done by cluster technique. This research is analyzed by rational choice theory which assumes that people are always trying to optimize the choices that bring benefits (Mallarangeng 2008: 9, Kuper \& Kuper 2000: 895). The study had various findings, such that public support of the king could not be explained by the concept of Javanese power and that logical consideration in the form of the interest proximity of each group becomes a concept of public support against the king. When the group interests are closer, they show their support, but, when the gap becomes wider, they readily change their support without fear of karma.
\end{abstract}

Keywords: concept of power; community support; interest distance

\begin{abstract}
Abstrak
Latar belakang penelitian ini adalah adanya dukungan dari masyarakat Yogyakarta terhadap sultan untuk memimpin Daerah Istimewa Yogyakarta. Penelitian ini bertujuan untuk mendeskripsikan hubungan antara raja dan masyarakat di era demokrasi. Penelitian ini mengambil kasus konflik RUUK DI Yogyakarta, konflik Sutet, dan kasus Pasir Besi di Kulonprogo. Metode penelitian yang digunakan adalah metode kualitatif dengan teknik pengumpulan data dokumentasi, observasi, dan wawancara. Teknik pengambilan informan dilakukan dengan teknik cluster. Penelitian ini dianalisis dengan teori pilihan rasional yang berasumsi bahwa manusia selalu berusaha mengoptimalkan pilihan-pilihan yang membawa keuntungan (Mallarangeng 2008:9, Kuper \& Kuper 2000:895). Penelitian ini menemukan bahwa "konsep" kekuasaan Jawa tidak lagi bisa digunakan untuk menjelaskan dukungan masyarakat kepada raja. Penelitian ini menemukan bahwa dukungan kepada raja terjadi karena kesamaan jarak kepentingan. Ketika kepentingan masyarakat bersamaan dengan raja maka masyarakat akan mendukungnya, namun jika kepentingan mereka tidak lagi sejalan dengan kebijakan raja maka mereka akan berani melawan raja tanpa takut akan kualat.
\end{abstract}

Kata kunci: kekuasaan dinamika; dukungan masyarakat; jarak kepentingan; kultur politik

\section{Introduction}

In the middle of democratization which grows from the city to village. When all of the communities celebrate the election process as the result of democracy and practice it massively, starting from a formal position with a high salary to sub-district position with full of devotion. However, in Yogyakarta, it shows different phenomenon. Yogyakarta Governor is not chosen directly by the society instead it reigned and appointed based on his genealogical dynasty.

Nevertheless, the support from the society towards sultan in many cases is still strong. The survey and polling result in several institutions make Yogyakarta society prefer to choose the determination of the governor to direct the election (Wahyukismoyo 2004:152-155). Even when there was polemic of Keistimewaan Yogyakarta Law Program which was dominated emerged from the people who pro with the determination of Yogyakarta Governor. The support seems strong since the researcher observed the banners which were installed in every corner of Yogyakarta. There are referendum aspirations in some crossroads but in the main roads, they replace red and white flag (Indonesian flag) into coconut sugar flag which is written Ho Bo as a symbol of Yogyakarta palace. 
The support of the sultan or king of Yogyakarta is also emerged from the election result of DPD member since 2004 until now. This is then resulting in Gusti Kanjeng Ratu (GKR) Hemas (empress of Yogyakarta palace) win the "fight" with an absolute victory. Related to the tropical storm disaster issue in 2006, society had conducted non-rational action by making "lodeh" which was from sultan because he wanted the society doing their activities rational ways (Kompas 7 February 2005).

The support of Java society to the king was explained by the idea of Java Authority/Kerajawian Theory. Moertono (1985) and Anderson (1986) explained that the Java society support toward the king happened because the society had social construction about Java authority concept which considers king as a superhuman figure who had supernatural power (Handayani \& Novianto 2004: 103, Moertono 1985: 42, 48, 49). The collapse of the authority can only happen through the loss of revelation from the leader in regards to the disappearance of fertility, prosperity, stability, and sublimity of an area (Anderson 2000:18-19).

The justification of high position of the king in Java is never based on material things, such as wealth or the amount of army that is being controlled, but more in the inner greatness of the king (Laksono 1985). The belief factor that owned by the society makes they look at the king as a charismatic figure. This finding is not only happened during independence era but it already happened during republic era when Sultan Hamengku Buwono IX hold the power (Soemardjan 1981, Atmakusumah 1982, Suwarno 1994, Suratmin \& Rudianto 2008). Even in the reform era, most of the society did not elect the candidate because they were afraid to betray the sultan (Darmawan 2010:209, Setianto 2011). In addition, the society also used a non-rational method such as magic in influencing the village head election process and this is not only happened in Yogyakarta but also in two sub-districts in Banten (Humaeni, 2014:14, 25).

The number of the society's support in the contestation that related to the "Undang-Undang Keistimewaan" in Yogyakarta, showed that the society is always loyal towards the king. Since that it can be linked back to the past that the society belief and knowledge toward the idea of Java authority still exist. In the other hand, considering that Yogyakarta is experiencing the changes to the more rational thinking, more people with high education, egalitarian, and makes almost all of the succession of the public position is conducted through direct election mechanism.

\section{Research Method}

This research is aimed to describe and understand the behaviour of Yogyakarta society that related to the support of traditional leader in the modern era. The research is conducted by investigating the case which is related to the contestation that involves society, sultan, or nobles after the reform era. There are three cases that were used in this research. The first is the constellation case of "UndangUndang Keistimewaan" Yogyakarta (2003-2010), the second is the construction conflict of Iron Sand factory in Kulonprogo in 2006, and the third is Sutet conflict in Kersen Bantul (2005).

The informant collection techniques are using cluster method. This step is used to take informant based on their groups (classes) who involved in the conflict (Teddlie \& Tashakkori 2009:173). Informants in this research are the people who involve in those three conflicts. Related to the first case, Rancangan Undang-Undang Keistimewaan Daerah Istimewa Yogyakarta (RUUK DIY) contestation, the researcher interviewed informants who came from pro-determination groups, namely village custody, political party, civil servants, and pedicab drivers in Malioboro who involved in a demonstration of RUUK DIY. In the second iron sand case, the researcher conducted the interview of coastal farmer community in Kulonprogo and village custody. The third sutet conflict, the researcher conducted the interview of custody and people who involved in Kersen sub-district's conflict. Data collection is conducted through observation, interview, and documentation.

\section{Result and Discussion}

\section{RUUK DIY Case: The Concern and Dynamic of Fluctuative Support}

When we reviewed the case of RUUK DIY, at first it seemed that the support of the people in Yogyakarta against the sultan was very great. However, when we observed carefully, the chronicles 
history of the society movement that related to Yogyakarta seems there is inconsistency support. If the support was based on the construction of the Java's authority, it should be consistent. Nonetheless, each group has a unique support dynamics towards the Sultan. The loyalty of the group action depends on their interest as well. This pragmatic concept of support is compatible with rational chosen theory, which assumed that people are always trying to optimize the choices that bring benefits to them (Mallarangeng 2008: 9, Kuper \& Kuper 2000: 895).

In 2007 until the 2009 election, Golkar (political party) was clearly seen as the leading party in carrying the determination governor election in Yogyakarta. Golkar's figures dub themselves as goalkeeper of privilege. Even in the midst of Hamengku Buwono (HB) X controversial statement, he said that he was unwilling to be the governor again. However, Golkar became the only political party that persisted in developing support for the appointment of the governor by using the jargon "my sultan my governor." This Golkar's persistence gave a "change" in the sultan attitude, that he still unwilling to be a governor. After the election was over and Golkar's vote was decreasing, while the party that held the Yogyakarta governor's election increased its vote, causing Golkar to turn around. Then, the attitude of the Sultan who tended to be more active in Nasdem (National Democrat) which at that time was suspected to be the new political party and became Golkar rival. Afterwards, in the era of 2010, Golkar struggled to legalize RUUK DIY was stopped. Golkar even reviewing its support and ready to reverse for the sake of the election.

The rejection support can also be seen from the Bantul group. Bantul Group is a community group organized by Bantul Government to support RUUK DIY. Support of Bantul group against the determination of RUUK DIY was very strong in 2003 to 2007. In 2003, Idham Samawi (Regent of Bantul) as the frontman who defended the determination was reciprocated by HB X by entrusting Idham in the Bantul Election despite HB X's younger sibling. Nevertheless, the support of the Bantul Group was weakened, since that it is difficult to stop sultan family privilege in the period of 2008 to 2009, that was the most crucial period. Legislation in Indonesia limit the public position (Yogyakarta governor) for two periods and HB X had served the Yogyakarta for two periods.

During those periods, the Bantul group has no longer become a militant group. The RUUK DIY was struggled by Sleman Group which was close to Pakualam. In that period the Bantul group brought under discourse "my sultan my president". Even Forsekdesi (Village Secretary Forum), one of the elements in the Bantul group. On December 19, 2007, he stated that he was no longer participate in the issue of the determination because it becomes the desire from Sultan HB X in Pisowanan Agung not to become the governor again (Source: Kedaulatan Rakyat, Sultan Tolak Gubernur Seumur Hidup: Kontraproduktif Bagi Rakyat DIY, 6 March 2008, Kedaulatan Rakyat, Tiga Spirit Harus Dijaga Rakyat DIY: Sultan Tak Ingin Selamanya Gubernur, 6 September 2011; Kedaulatan Rakyat, Merti Nusantara Siap Dukung Sultan, 13 January 2009).

The Sleman group also cannot be said to be a loyal group to the sultan if they see the dynamics of their actions. Sleman Group consists of custody who were the members of Paguyuban Ismoyo and Cokropamungkas, where the leader was from Sleman. The Sleman group was the most decisive group in demanding the determination of the sultan as governor. However, the Sleman Group was not afraid against the wishes of the king when he declared himself as a presidential candidate. Even Sleman group brave in saying if HB X unwilling to be a governor, he should abdicate the throne to be replaced by the new sultan (HB XI). One of the narrations that related to the reasons of the Sleman Group is that if the RUUK DIY can be accepted. Then the structure of the DIY government can be restored as it used to be. It is important because the current governance village structure does not stand in the custody. In the past, custode's length of service was for all their life-time. Over time the position becomes limited, even restricted for five years. Although later it changed to be in ten years, then it changed again to be in six years, and the last is in eight years. The perceived policy is not procustody anymore and it can be solved if the government structure in DIY returns to the past structure as the consequence of DIY privileges (Interview with one of the custodes in the commemoration of 
No X on September 5, 2010 at SMA 11 Yogyakarta); Interview with Mbah Mulyadi the village head of Sidomulyo, Sleman and the head of Ismoyo (association of village head of DIY) on January 23, 2010 at his home).

If we examine the groups that organize the action, they have no construction of the theory of kingship. The loyalty of the action group is closely related to the interest loyalty, not loyalty towards the figure of the sultan. Therefore, when the sultan said the election, the attitude of the group can be referring to the determination or the election. This group even brave to criticize HB X without fear of qualification. They had the conviction that the sultan is an ordinary human, he could be wrong. They do not believe that the sultan is owned magic and married to Kanjeng Ratu Kidul. When they asked about the reasons for the determination, most of the elite responded normatively that Yogyakarta is served as historical narratives that must be respected.

The Bantul group is dominated by civil servants and village custodes. The mass action of this group appeared to be elitist and depend on the order of the structural line, through a linear bureaucracy. The actions of the Bantul group were generated because of the encouragement of the district head and the bureaucracy. When the regent appeared to support the determination, the officers underneath did not want to be left behind in those subsequent events. On the contrary, when the regent was silent, most of the Bantul Group also being silent. The mass of civil servants was coordinated by the top officials, such as heads of agencies, bodies, or heads of offices. In the educational environment, teachers were also involved because of their school principal's advice. Since that the principals receive the orders from the head of the Technical Implementation Unit (UPT) of the sub-district, head of department and PGRI (Indonesian Teachers Association) of Bantul. These groups also being directed from a higher group in Bantul regency government. In the other institutions, such as employees of Bapeda, Bawasda, and almost all institutions in Bantul regency were also being conducted because of the order from their top hierarchy from their organization (Observation of the authors in Pisowanan Agung on April 18, 2007 and interview to one of the head office in Regional Government Bantul on the same day; Kedaulatan Rakyat, KR Group Peroleh Penghargaan: Ribuan Warga Bantul Aksi Ke DPR, April 28, 2008).

During the demonstration, it was clear how Bantul regency mobilized the village officials and its bureaucracy. Official uniform, red plate vehicles, local government buses, or funds, as well as mechanisms of attendance also determined the privileged of the protestors. In the bureaucracy, there was a patok culture which means that when the bureaucracy gives the command, then the bureaucracy at the lower level must do the command. Since that the bureaucracy at the top level is a patron which had to be followed by the lower level employees. It also has the ability to present the punishment to the subordinate who disobey the advice from their superiors. In a bureaucratic culture, the lower level employees will always follow the bureaucracy, although they do not like it. "Banana tree is falling, if the upper part turns left then it should turn left, but if it turns right, the lower part should turn right" this is the principle of bureaucracy. If you do not want to be punished by the top-level then the lower-level officials should follow the advice from their superiors. Loyalty to the leader is sacred or purified value (Supriyono 2005: 89). It is commonly accepted as social fact, outside the individual, and forcing everyone to obey their superiors. The devotion to the "sacred" even represents the classification between loyal and disobedience employees. If an employee wants to receive a reward, they have to uphold this "sacred" value.

The story of the people who are actually leaning into elections, yet being involved in the act of determination shows that the mobilization process is elitist and everyone upholds the "sacred" Values. Although they think that the election will make Yogyakarta more dynamic, since that the district government has decided the determination then they just follow it, and not really affected them. Thus, there are also employees who are involved in the action, only because of the organization, either because of the loyalty to their superiors, valued their togetherness, or fear towards the bureaucratic structure. The cause is none other than the "mutual agreement" and obedient to the bureaucratic advice (Interview with SBO, one of the heads of Bantul Regency on November 30, 2010, at his home). 
The way of people's thinking is not only to the Bantul Group's civil servants. One of the village chiefs said that because the organization has decided the action and every urban village have to be involved, so he also participates in the action. Support for determination is a form of their solidarity and obedient with the organization. The determination has been the decision of the village apparatus association (either Apdesi or Ismoyo). This means that the village apparatus are being "forced" to support the establishment. Although they think that elections are a good alternative to the advancement of DIY, but the organization makes them have to act as the defenders of the determination and send their people to engage in the action (Interview with SO, one of the headman in Kulonprogo on June 15, 2010 and MDI, one of the headman in Sleman on January 23, 2010 at his home).

In addition to structural factors, in supporting the sultans was easily pulled into a pressure group because it has a passive narrative on the king figure as a protector of the society. This value turns as a hope for all the community groups in Yogyakarta. Although the old myths related to the magic of the Javanese king began to disappear and became an unbelievable fairy tale, yet the society also built a more rational new myth. These new myths resulted in a high public appreciation of the sultan. The modern myth built in the Javanese society describes that a king will become the patron of the poor people. The king is impossible to carry out evictions, the king must stand up for his people in order the people will feel protected and make them respect towards the sultan. In the becak drivers community, the sultan's beliefs will not evict or ban the pedicab drivers from entering the city. Pedicab drivers are never driven from the streets of Yogyakarta. Therefore many people believe that if Yogyakarta led by other people instead of the sultan there will be a ban on pedicab drivers. Sultan perceived as a good leader, protect and generous to his people. These positive images are in parallel with the myth that the king's throne must be for the welfare of the people. It made the public respect for the sultan (Interview with Paimin, a Pundong society who works as a pedicab driver who hung in Malioboro on September 4, 2010).

The construction of sultan's positive image in the eyes of the society is a collective memory that remained in the social stock of knowledge which moving towards rationality. Halbwachs explained that the collective memory or memory is the guardians of the tradition that builds the integrity of society. When a society experiences disorientation, collective memory becomes an energy for the nostalgia, that able to maintain the cultural ties (Supriyono 2005: 106). The knowledge reserves of the people of Yogyakarta are related to the nature of the past king who is practicing the teachings of astabrata (Moedjanto 2001: xi, xv), and has manunggaling kawula-gusti principle, which served as a fence for the king to always be a good man. The concept of the throne for the people was practiced by HB IX, that produced through books, and word-to-mouth stories strengthened the reserves of that knowledge. This reserve of knowledge gave birth to the collective memory of the Yogyakarta subjects concerning the figure of a benevolent king, anti-corruption, always concerned and fulfil the interests of his people (Atmakusumah 1982, Wardani 2012: 62). The concept of the throne for the people of Soempeno also wanted to be attached to HB X in relation to the competition for Indonesia president election in the year 2009.

The assumption is a myth that people believe and used as one of the considerations to behave in the RUUK DIY. As long as these assumptions were well preserved, the society would give their support to the king. When it clashes with the nearest pragmatic interests, these assumptions are ignored and the community is boldly confronted against the sultan. Loyalty to the sultan and Javanese theory are different from the theory in the Javanese past. The modern myth loses its mystical character, therefore it was not based on the assumption that the king served as a superhuman supernatural person who could not be wrong. They dare to protest and utter the criticism towards the sultan (HB X) if he made miserable policies. Such as creates a new policy that prohibits pedicab drivers from entering the city, which will threaten the economic interests of pedicab drivers then they dare to oppose the Sultan's policy. They were more afraid of their economic interests being threatened rather than fear towards the king's qualities. Thus, it can be concluded that one of the support for the determination among pedicab drivers occurs because of the positive image of the sultan as a guardian who protects their interests. This is as stated by Paimin: 
"If the governor and the sultan are separated (elected through the general election) we will be confused, however, if there is a problem, then people will go to the sultan. Under Ngarsodalem $(\mathrm{HB} X)$ there is no riot, we are safe, there are no prohibition rickshaws, if the governor is not a sultan, pedicab driver can be prohibited. The same situation like in another city, if we forbid the protestor, ngarso dalem may not forbid pedicab drivers because he is the king, the protector for low-class society “(Interview with Paimin, pedicab that hung in Malioboro on September 4, 2010).

\section{Iron sand case and loss of support}

The case of land conflicts in the coast of Kulonprogo reinforces the narrative of the people's loyalty to their king. That occurs when the modern myth of a kind-hearted king ensures the lives of his people are preserved. However, when society feels harmed by the change from the king's attitude, they dare to resist and overthrow the old myth without fear against the King's policy.

People on the coast of Kulonprogo have similar knowledge from most of the Javanese people. Basically, they are the ones who respect the Sultan and Pakualam as the leaders. There was no protest over the leadership of HB X and Pakualam regarding his appointment which not through the election mechanism. Even in 2003, when the election of legislative members happened, the empress sultan, GKR Hemas participated in the election competition of DPD RI members. At the end, GKR Hemas won the battle in coastal areas with an absolute vote. On the other hand, different result occurred in the 2009 election, where a total number of the ballot voted GKR Hemas in the southern coastal area of Kulonprogo plummeted. Although the overall number of GKR Hemas voters in Kulonprogo showed an increase from 834,130 (2004) to 941.153 (2009), in the southern hamlets of Jalan Dandles showed a significant decline. In Bugel II Village, Cholid Mahmud was able to get ballots nine times than GKR Hemas. Whereas in previous elections GKR Hemas won in this area. The loss of GKR Hemas sounds not only in the hamlet of Bugel II but in almost all villages in coastal areas of Kulonprogo affected by iron sand projects such as in Bugel I, Pleret I, II, III. However, the number of hamlets affected by the iron sand project is not much. Therefore, district levels, there is no significant voice change. From the 88 villages in Kulonprogo, only five villages were affected by iron sand projects $(5.6 \%)$.

The change in the ballot of GKR Hemas in the hamlets is affected by the iron sand project. Which indicated a change of public support to the king which caused by their conflict of interest with the government and the nobles. The iron sand conflict that occurred since 2006, affect the attitude of society to the king and his family. Positive imagination about the king's protective figure is lost in their knowledge. They became courageous against the sultan policies and ignored the myths of the sultan's power. People's loyalty to the king is no longer "blind" about the loyalty, but rather than they turn their loyalty into more rational that considers profit and loss calculations to protect their economic interests. Community loyalty cannot be described in the jargon of "Pejah Gesang Derek Sultan". South coastal communities use the consideration of their ratios in the 2009 election.

The figures who have been defending the fate of the farmers are the people who are chosen in the 2009 elections. His name is Muhammad Ulinnuha, S.Hi in the district level, Adjie Kusumo (Bung AK) at the provincial level, Anwar Hamid, S.Sos at the central level, and Cholid Mahmud for the members of DPD RI are the favorite figures of the community along the coast of Kulon Progo. They have been the protectors who are expected to protect the community. People will think rationally to protect the interests of their production modal and the characters who support the interest of the poor people must have won. The management of PPLP (Paguyuban Petani Pulau Lahan Pantai) directs the community to select candidates who fight for the interests of the farmers and reject the figures who support the iron sand project.

Political choice of Kulonprogo coastal community shows the uniqueness, that can be seen from the background of political parties. The composition of elected leaders in the 2009 elections is not in one political party. Ulinnuha and Anwar Hamid came from Kebangkitan Bangsa Party (PKB) for the 
candidate of $D P R D$ II and $D P R$ RI respectively, while for the candidate province level changed to $P D K$ Party (Partai Demokrasi Kebangsaan). The figure of the PDK is also a nobleman (Pakualaman) who has a position that the opposite from the former ruling Pakulam. At the level of $D P D R I$, they chose Cholid Mahmud who was once a member of the board of the MCC. The PDIP vote which previously won in the 2009 election was over. For example in Bugel II Hamlet, where PDIP votes for the district, they only get two votes and for the centre, they get three votes from 302 residents. Whereas in Bugel I PDIP only get 10 votes. This is because of PDIP as the political party of the regent that supports the iron sand project which makes them receive only a few votes. Even in the event of an anti-sand iron attack post, the society suspect that some people are PDIP sympathizers (Kompas.com, Iron Sand Conflict, Coastal of Kulon Progo Tegang, October 29, 2008, and interviews with Supriyadi and Sukarman dated November 12, 2008). Demokrat and Golkar Party ballots that did not defend the interest of the poor people did not receive many votes in coastal areas, although they did not drastically decrease like happened in PDIP. The political flow that happened within the society in the coastal area is unable to explain the society's choice in conflicting villages. People do not simply vote for parties, but they choose the people they want, who have been providing direct support or through their cadres into community struggles.

\section{The Conflict Case of Sutet Construction in Kersen Bantul}

The case of Sutet is one of the events that shows how tradition is used as a means of struggle to solve the problems. Towards the middle of 2005, in Yogyakarta, there was a conflict between State Electricity Company (PLN) and Kersen society. The conflict was stemmed from the PLN project to fulfil the Java power supply by building the High Voltage Air Channel (SUTET) along the southern route of Java Island. One of the Sutet passed through Bantul precisely in Kersen Teruman, Bantul.

The project raises a concern about the impact of radiation on public health around the giant pillars of the Sutet buffer. The concerns were realized in the form of protests to PLN, that will make the construction becomes protracted. Although Bantul Regency had helped to mediate between the citizens and PLN, the problems still unsolved. At the time of the deadlock, the people of Kersen took a unique decision that seemed to show the remnants of the idea of Javanese power. The people suddenly asked the King (HB X) to play as a third party who was not merely positioned as a mediator. However, the sultan played a role as court-arbitrators whose every decision would be obeyed by the community. As a condition, HB X did not play the role of the governor but as King of Yogyakarta Sultanate. All decisions that issued by HB X did not use the local government header, but the Palace of Yogyakarta Sultan. The attitude which was taken by Kersen society was almost the same as the desire of toy entrepreneurs and street vendors $(P K L)$ in the area of South Square. They ask the palace to socialize the arrangement for the square use, rather than asking the city government which had more formal authority (Kedaulatan Rakyat, Socialization of the Arrangement of Alkid: PKL Asks the Palace to Do, 17 December 2009, page 3).

The story is almost the same as the inhabitants of Plengan, Banjaroya, Kalibawang. They were asked to provide old teak wood to build one of the damaged palace buildings (Trajumas wards) but they came to ask the sultan himself. The decision of this society is quite strange because in the Javanese belief it is impossible for a king to take or ask for the people's property in a straightforward manner. Thus, there is an impression that the attitude is just a community strategy to reject the demand. In the Javanese concept, the King asks or governs were not straightforwardly, but by using the symbolic language (sasmita). In the Javanese culture there is the concept of dupak kuli-dugang bujang, semu mantri, esem bupati, sasmita narendra (dupak: kick, kuli: blue-collar workers, dugang: kick with hind legs, semu: satire, mantri: sub-district leaders, esem: smile, sasmita: symbol, narendra: nobleman, king). This expression gives the knowledge that the person must act (language) in adjust with whom they are dealing with (KRjogja.com, Jati Kembar for Traju Mas Kraton: Warga Rela jika yang Minta Ngarso Dalem, 9 July 2009).

In the case of Sutet, before the society met Sultan HB X, they had met several times with the 
deliberations of regional leaders (muspida), ranging from the regent to the police. In one of the meetings, people was wearing Javanese traditional clothes to show that they are kawulo or people from Keraton Ngayogyakarta. After meeting with the officials of Bantul and PLN, they did not reach an agreement, they brought that matter to the palace. In this section, residents seemed wanted to show that they were Javanese people who had Java values and beliefs. It appears from the people physically impression such that they looked like Javanese people, they also showed their Javanese language. This incident confirmed that the emergence of a narrative in the Kersen society that the king was just an ordinary man and could not possibly harm his people. This makes the protracted problem was sought by the king's decision.

The Sutet conflict in Kersen is a unique case because the event seems to show people's conviction that the sultan's words are always right and wise that must be followed. The Sultan as the righteous king, he obliged to protect the society according to the narrative in the idea of Javanese power. This belief comes from the hearing and obedience of the most societies towards the sultan words. Before the king made any decision, the people had made the decision to totally accept what the sultan said. From this illustration, it appears that the cultural leader has a legitimacy in the settlement of an emerging social crisis and linked to the legal-formal government structure (Susanto 2005). All the deadlock problems can be solved by presenting the figure of the sultan in the community. Since that there is still a value of cultural compliance or a minimum of public confidence in the sultan power. This suggests that in an ordinary situation without conflict as well as with the king's support, the palace power are still strong. However, the loyalty to the sultan and the theory of the kingship will be lost when the romanticism of the good sultan is lost.

The signs arose when there were people who had the courage in questioning the merits of the king's decision, even though there had been adequate compensation. Some people evaluated and criticized the decisions by the king. They were no longer blind towards the king who was usually considered has magical power. There also a critical attitude to the king's steps when the king's decision is inconsistent with the beautiful shadow of the society. This becomes evident in the minds of the readers of SKH Kedaulatan Rakyat who questioned the sultan's decision. Which because the people still suffered losses, as the letter appeared in the mind of the Pikiran Pembaca Kedaulatan Rakyat written by Ir. H. Moekarno who questioned the justice for the society in the Sutet conflict in Kersen (Moekarno 2007).

From the incident, it seems that when the decision was taken by the king to give an advantage to the community then the decision will be obeyed, but if it is harmful they will protest. Thus, it seems that asking the king as a jury is not a reflection of the idea of Javanese power, but it is a community strategy to keep his interests protected in the community in a difficult position. Even the Javanese outfit used in the dialogue with the Bantul rulers did not show Javanese culture since that in the rally there was an oration, people were screaming to make noise. Javanese dress is more interpreted as a means to attract the media and obtained the attention of the public and the sultan. There is even an impression that the public deceives the sultan because before the decision comes a statement in the media will accept whatever the sultan's decision. Nevertheless, when the decision is taken and the result is not satisfactory, the community brave to question the sultan's decision. Thus, the tradition is no longer exists and the positioned served as the character and behavior of the society. Right now they used it with rationality in the use of old traditions in order to achieve the group interest.

\section{Conclusion}

At first glance, the public support for the king seems unchanged since the past, but if we examined closely, the allegation is misplaced. The three cases in the discussion section indicate a change of support base in the Yogyakarta community that affected the pattern of community support for the king. The public support for the sultan is no longer as steady and consistent as the Javanese power theory's conception, but the support is dynamic and changing according to the interests. 
People's support for the king is extremely strong when the interests of one group in parallel with the interests of the king. Nonetheless, people support will decrease, disappear, and become contradictory when the interests of their group are neglected or threatened by the Sultan's policy. The public is no longer afraid of accurst to deprive the support of the king. Nevertheless, interest theories, such as a rational choice theory or economic base (Marx) also cannot be used to explain the pattern of support (relationship) society to the king in replacing the theory of power in Java (Moertono \& Anderson). Although the actions of community groups are guided by the interest, they are bound by local languages (community values) so that they will afraid to act out of the public's best interests, unless their main interests are cornered.

The old knowledge of the king's wise nature, as the man who always nurtures the society in the concept of manunggaling kawula gusti internalized and stuck in the knowledge of society. According to the sociological perspective, knowledge is not easily disappearing from the reserves knowledge by the society, and it will become a home world that will always be remembered. Consequently, the people who never had a conflict with the sultan, highly appreciate and show a great support for the king. The community was afraid to build the imagination of the other Yogyakarta, without the sultan. Because of the knowledge during this time the sultan has played a satisfactory role as the guardian of the Yogyakarta people. Therefore, if the community's support for the sultan is very strong because most of the people in Yogyakarta have known that the king must be a good man, except in the areas where the sultan violates his image as a protector of the society. As long as the knowledge is satisfactory functioning (pragmatic), people are generally willing to suspend it. Although the community has accepted and practiced direct democracy in daily life, the community ignored the system in selecting the successor mechanism of Yogyakarta governor because the determination mechanism did not cause the problems for the people in Yogyakarta.

\section{References}

Anderson B (1986) The Idea of Power in Javanese Culture, diterjemahkan menjadi Gagasan tentang Kekuasaan dalam Budaya Jawa. Dalam: M Budiardjo. Aneka Pemikiran tentang Kuasa dan Wibawa. Jakarta: Penerbit Sinar Harapan.

Anderson B (2000) Kuasa Kata: Jelajah Budaya Politik di Indonesia, Mata Bangsa, Yogyakarta.

Atmakusumah (1982) Tahta Untuk Rakyat: Celah-celah Kehidupan Sultan Hamengku Buwono IX. Jakarta: Gramedia.

Darmawan A (2010) Jogja Bergolak: Diskursus Keistimewaan DIY dalam Ruang Publik. Yogyakarta: Kepel.

Handayani C \& Novianto A (2004) Kuasa Wanita Jawa. Yogyakarta: LKis.

Humaeni A (2014) Penggunaan magic dalam politik lokal di Banten. Masyarakat, Kebudayaan dan Politik, 27 (1):14-26.

Kedaulatan Rakyat (2008) Sultan Tolak Gubernur Seumur Hidup: Kontraproduktif Bagi Rakyat DIY, 6 Maret 2008.

Kedaulatan Rakyat (2009) Merti Nusantara Siap Dukung Sultan, 13 Januari 2009.

Kedaulatan Rakyat (2009) Sosialisasi Penataan Alkid: PKL Minta Kraton yang Melakukan, 17 Desember 2009.

Kedaulatan Rakyat (2011) Tiga Spirit Harus Dijaga Rakyat DIY: Sultan Tak Ingin Selamanya Gubernur, 6 September 2011.

Kompas (2005) Antara Mitos Keraton dan Kearifan Lokal. Kompas, 7 Februari 2005.

Kompas.com (2008) Konflik Pasir Besi, Pesisir Kulon Progo Tegang, 29 Oktober 2008.

KRjogja.com (2009) Jati Kembar untuk Bangsal Traju Mas Kraton: Warga Rela, jika yang Minta Ngarso Dalem. KRjogja.com, 9 Juli 2009. 
Kuper A \& Kuper J (2000) Ensiklopedi Ilmu-Ilmu Sosial: 2. Jakarta: Raja Grafindo Persada.

Laksono (1985) Tradisi dalam Struktur Masyarakat Jawa Kerajaan dan Pedesaan: Alih-ubah Model Berfikir Jawa. Yogyakarta: Gajah Mada University Press.

Mallarangeng R (2008) Mendobrak Sentralisme Ekonomi Indonesia 1986-1992. Jakarta: Gramedia.

Moedjanto G (2001) Konsep Kepemimpinan dan Kekuasaan Jawa Tempo Dulu, dalam Hans Antlov dan Sven Cederrroth, Kepemimpinan Jawa: Perintah Halus, Perintah Otoriter. Jakarta: Yayasan Obor Indonesia.

Moekarno (2007) Surat Terbuka Kepada Gubernur DIY, Pikiran Pembaca KR, 15 Januari 2007.

Moertono S (1985) Negara dan Usaha Bina Negara di Jawa Masa Lampau, terjemahan dari State and Statecraft in Old Java: A Study of the Later Mataram Priod, 16th to 19th Century, Cornell Modern Indonesian Project. Jakarta: Yayasan Obor Indonesia.

Setianto WA (2011) RUUK DIY dalam Perspektif Budaya, Kedaulatan Rakyat, 19 Januari 2011.

Soemardjan S (1981) Perubahan Sosial di Yogyakarta. Yogyakarta: Gajah Mada University Press.

Soempeno FA (2009) Pemimpin dengan Tahta Rakyat. Yogyakarta: Galangpress.

Supriyono J (2005) Paradigma Kultural Masyarakat Durkheimian. Dalam: M Sutrisno \& H Putranto. Teori-Teori Kebudayaan. Yogyakarta: Kanisius.

Suratmin \& Rudianto D (2008) Sri Sultan Hamengku Buwono IX: Pejuang dan Pelestari Budaya. Yogyakarta: Penerbit Navila.

Susanto A (2005) Satu-satunya daerah istimewa yang tak lagi istimewa. Kompas, 21 Oktober 2005.

Suwarno PJ (1994) Hamengku Buwono IX dan Sistem Birokrasi Pemerintahan Yogyakarta 19421974: Sebuah Tinjauan Historis. Yogyakarta: Kanisius.

Wahyukismoyo H (2004) Keistimewaan Yogyakarta vs demokratisasi. Demokratisasi dan keistimewaan: Proses perubahan tata Pemerintahan Daerah Istimewa Yogyakarta. Tesis, Universitas Gadjah Mada. Yogyakarta: Bigraf Publishing.

Wardani LK (2012) Pengaruh pandangan sosio-kultural Sultan Hamengkubuwana IX terhadap eksistensi Keraton Yogyakarta. Masyarakat, Kebudayaan dan Politik 25 (1):56-63. 